\title{
Mediating Role of Psychological Hardiness and Perceived Social Support on the Relationship between Spiritual Intelligence and Happiness in the \\ Elderly Women
}

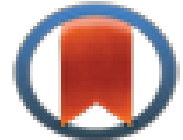

CrossMark dikk for updates

\section{Shahsavarn $\mathrm{R}^{1},{ }^{*}$ Ghaffari $\mathrm{M}^{2}$, Makhtoum Nejhad $\mathrm{R}^{3}$}

1- MA in Psychology, Department of Psychology, Sari Branch, Islamic Azad University, Sari, Iran.

2- Assistant Professor, Department of Psychology, Faculty of Humanity and Social Sciences, University of Mazandaran, Babolsar, Iran. (Corresponding Author)

Email: m.qaffari@umz.ac.ir

3- BA in Psychology, Department of Psychology, Faculty of Humanity and Social Sciences, University of Mazandaran, Babolsar, Iran.

\section{Abstract}

Introduction: Given the importance of happiness in old age, it is important to propose and test a multivariate model for relations between its predictor factors. In the present study, the conceptual model of the relationships between spiritual intelligence, psychological hardiness, perceived social support, and happiness was tested in elderlies.

Method: The research design was correlational. A sample of two hundred and eleven old woman, were selected through convenient sampling from four cities in Mazandarn province, Iran in the summer of 2016. All participants were asked to complete the Revised Oxford Happiness Inventory, The Spiritual Intelligence Self-Report Inventory, Ahvaz Hardiness Scale, and Multidimensional Scale of Perceived Social Support. The suggested model was tested through covariance-based structural equation modeling and data analysis was performed using the SPSS-22 and Amos-20.

Results: The mean age of the sample was $66.83(\mathrm{SD}=2.72)$ years old. Using maximum-likelihood estimation and bootstrap procedure, results from structural equation modeling showed that in the elderly women, spiritual intelligence through the mediating role of psychological hardiness and perceived social support, had positive and significant effect on happiness $(\mathrm{p}<.05)$.

Conclusion: According to the findings of the present study, it can be concluded that in elderly, higher levels of spiritual intelligence can predict higher happiness. Meanwhile, psychological hardness as a personal factor and perceived social support as an environmental factor can clarify the mechanism of the effect of spiritual intelligence on happiness. In other words, spiritual intelligence has a positive effect on the happiness through increasing psychological hardiness and, consequently, increasing perceived social support. These results can be used to design counseling programs for elderly people.

Keywords: Elderly, Happiness, Intelligence, Women.

Received: 6 December 2017

Accepted: 7 February 2018

\begin{tabular}{|l|l|l|}
\hline \multicolumn{3}{|c|}{ Access this article online } \\
\hline Website: \\
Www.joge.ir
\end{tabular}




\title{
نقشى واسطه اى سختكوشى رواذشناختى و حمايت اجتماعى ادر اك شله در رابطه هوشى معنوى و
}

\section{شادكامى در زنان سالمنل}

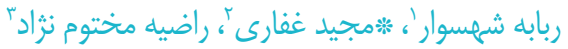 \\ ا - كارشناس ارشد روانشناسى، گروه روانشناسى، دانشخاه آزاد اسلامى، واحد سارى، سارى، ايران.

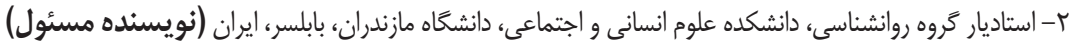

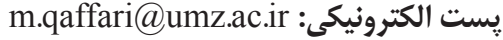 \\ "َ- كارشناس روانشناسى، گروه روانشناسى، دانشكده علوم انسانى و اجتماعى، دانشخاه مازندران، بابلسر، ايران.
}

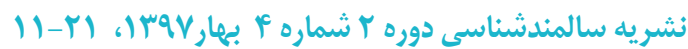

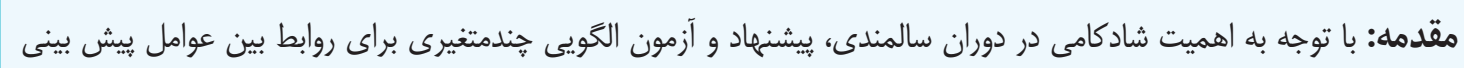

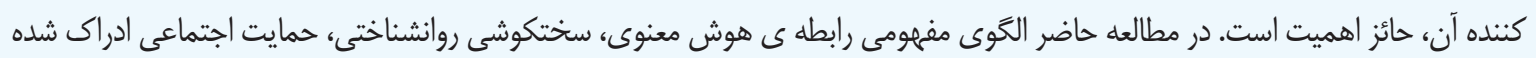

$$
\text { و شادكامى در سالمندان، آزمون شد. }
$$

روش: طرح يروهش حاضر، همبستخى بود. تعداد دويست و يازده نفر زن سالمند در تابستان هوسا با استفاده از روش نمونه كيرى

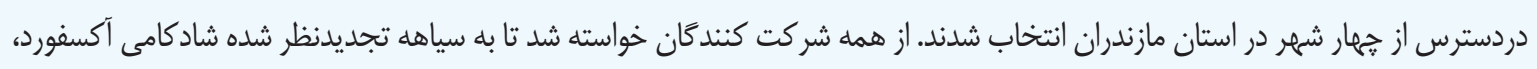

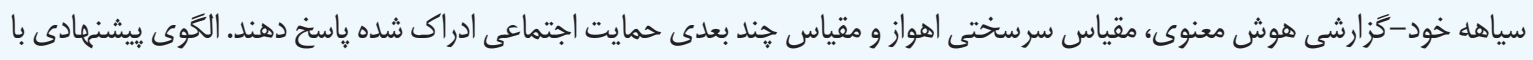

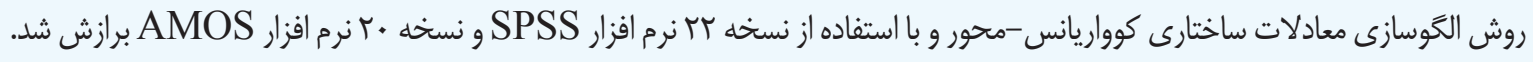

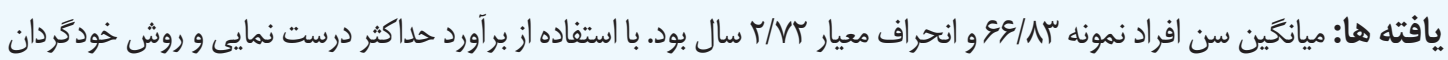

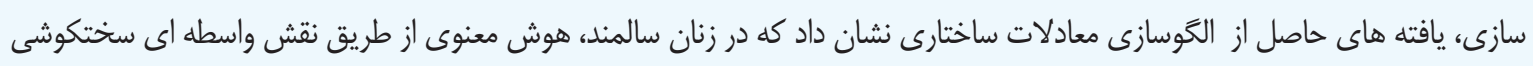

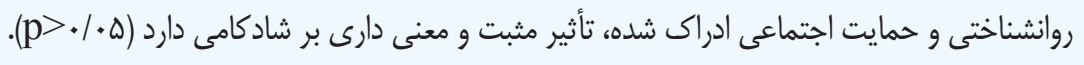

نتيجه كَيرى: بر اساس يافته هاى يزوهش حاضر مى توان حنين نتيجه كَرفت كه سطوح بالاتر هوش معنوى مى تواند شادكامى

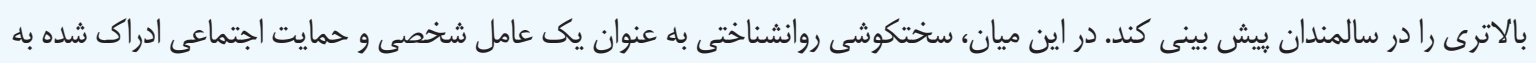

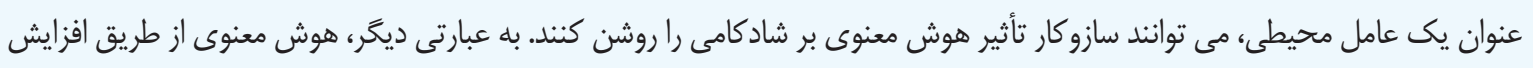

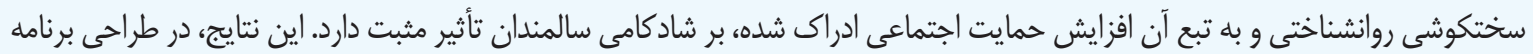

$$
\text { هاى مشاوره اى براى سالمندان، قابل استفاده است. }
$$

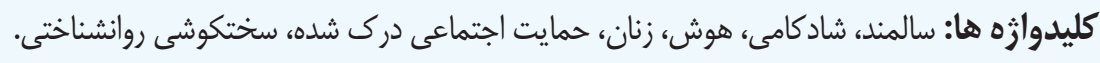


كننده عى علايه بالينى روانشناختى، به ويزه در افراد سالمند عمل

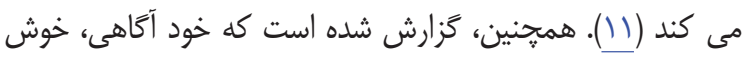

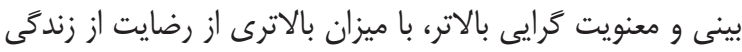
رابطه دارد (T) (I). هوش معنوى در مورد علم مديريت خود، مسئوليت در مقابل خويشتن و توانايى تشخيص كارهايى كه مى توانيم انجام

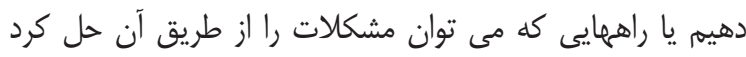

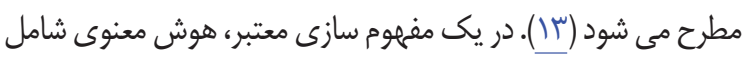
توانيى هايى از جمله: ا- تفكر انتقادى وجودى (ظرفيت انتقادى به ماهيت وجود، واقعيت جهان، فضا، زمان، تأمل و ساير مسائل وجودى مانند وجود متافيزيكى و نيز ظرفيت انديشيدن به مسائل غير وجودى در رابطه با وجود خود، به عنوان مثال، از ديدكاه اكز يستانسياليستى)؛ r- توليد معناى شخصى (توانايى استخراج معنى شخصى و هدف،

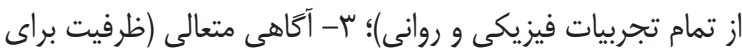
شناسايى ابعاد متعالى الكوهاى خود يا ديكران، و از جهان فيزيكى در حالات طبيعى هشيارى، همراه با توانيى شناسايى رابطة خود با جسم)؛ أ- توسعه ى حالت هشيارى (توانيى ورود و خروج به سطوح

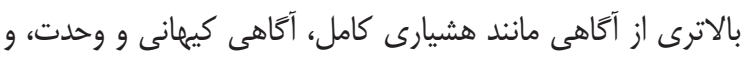

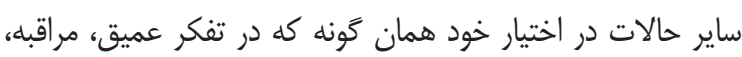
نماز، و غيره ايجاد مى شود) در نظر گَرفته شده است (سا). همانطور كه اشاره شد، برخى يزوهش ها بر تأثير مثبت عوامل مذهبى /معنوى بر سلامت جسم و روان از منظر آسيب شناختى تأكيد كرده اند، اما به

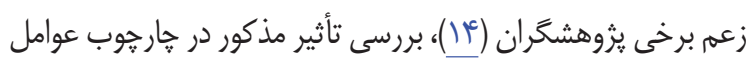
مورد تأكيد روانشناسى مثبت (از جمله شادكامى) به ويزه در سالمندان - كمتر مورد توجه قرار كَرفته است. انتخاب سازه ى هوش معنوى از اين جهت حائز اهميت است كه علاوه بر عنصر معنوى، بر هوش

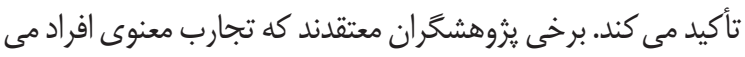
تواند به عنوان سازوكارى براى حل مسائل در مورد موضوعات مربوط به معنا و ارزش در نظر كرفته شود. بنابراين، از آنجايى كه هوش به به عنوان توانايى حل مساله و ساز كارى و انطباق با شرايط در نظر كرفته مى شود، مى توان معنويت را نوعى هوش دانست (fأ). با توجه به مباحثى كه مرور گرديد، در يزوهش حاضر، هوش معنوى به عنوان منوان ييش بين مهم شادكامى در سالمندان فرض شده است. هرجند برخى مطالعات كذشته به طور جداكانه به مباحث مربوط به عوامل مذهبى -معنوى و نيز شادكامى در سالمندان يرداخته

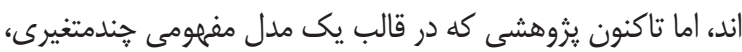
به بررسى تأثير هوش معنوى بر شادكامى در سالمندان و هرايى تأثير داني

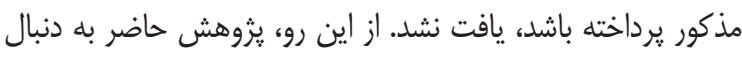

مقلمهه

در دوره ى سالمندى، سلامتى (health) و بهزيستى (well-being) مسائل و مشكلات مختلفى در حوزه هاى مربوط به روابط اجتماعى،

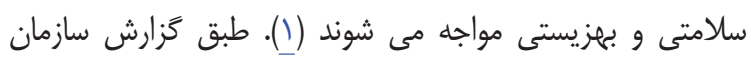
جهانى بهداشت، افزايش شاخص اميد به زندكى در ايران، در مردان ايرانى V Vال و در زنان ايرانى ال Wال است، كه نشان مى دهد آمار سالمندان ايرانى نيز رو به افزايش است. بنابراين سالمندى و شرايط الماليا

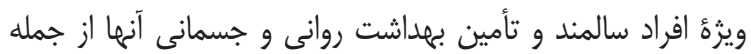
مسائلى است كه توجه ويزه اى را مى طلبد (با). توجه به سازه ى شادكامى (happiness) توسط روان شناسان و جامعه شناسان، طى دهه هاى اخير افزايش يافته positive است و يزوهشگران حوزه ى روان شناسى مثبت

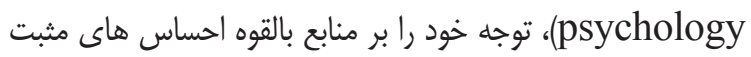

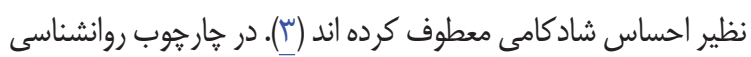
مثبت و فراتر رفتن بررسى سلامت روانشناختى از آسيب شناسى روانى (psychopathology) psychological) و بزيستى روانشناختى (strength) Well-being )، لزوم توجه به سازه ى شادكامى و يزوهش در در اين

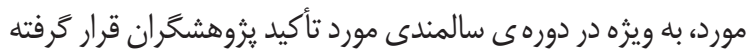

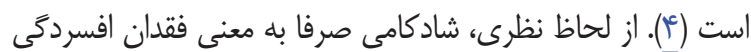
نيست بلكه نشان دهنده وجود حالتهاى شناختى و هيجانى مثبت شامل لذت، رضايت، آرامش و اميد است و مى تواند از افراد در برابر

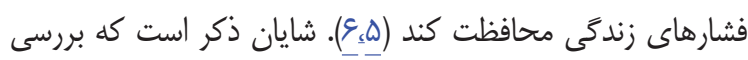
هاى طولى نشان مى دهند شادكامى بر طول عمر (longevity)

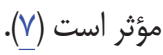
به نظر مى رسد، ابعاد معنوى زندگى انسان ها، مى تواند به عنوان يكى از بنيان هاى مهم شادكامى در نظر كرفته شود. جنانكه

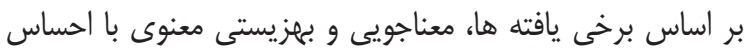
سلامتى، نشاط و عواطف مثبت در سطح روانى رابطه دارد (^). و Rebecca شامل ه19 بزر كسال مسن آسيايى دريافتند كه معناجويى با افزايش خشنودى، رضايت و كيفيت زندگى رابطه داشت (9). در همين راستا، هوش معنوى از ييش بين هاى رضايت از زندگى در سالمندان معرفى شده است (+1). بر اساس يافته ها، اعمال معنوى يا مقابله مذهبى به ديه

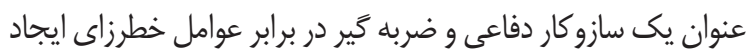


بهزيستى معنوى و سختكوشى روانشناختى قابل ييش بينى است

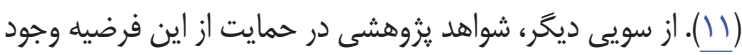
دارد كه معنويت مى تواند كاركرد روانى و سازكارى را تقويت كند

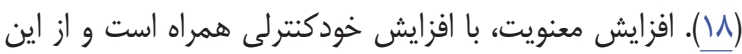

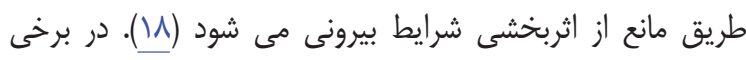

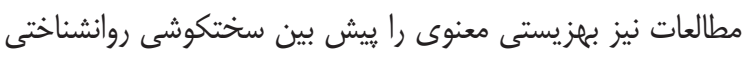

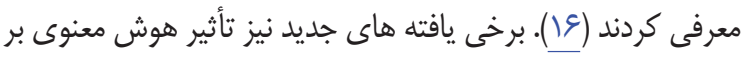

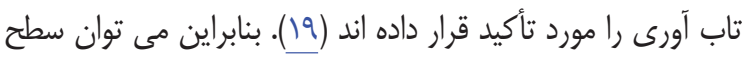

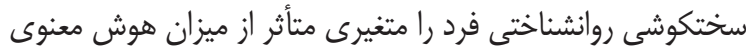

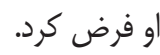

بر اساس مبانى ارائه شده، متغيرى كه مى توان در تبيين

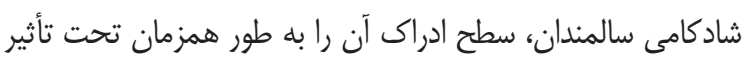
دو متغير هوش معنوى و سختكوشى روانشناختى در نظر كرفت،

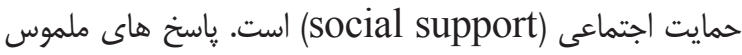

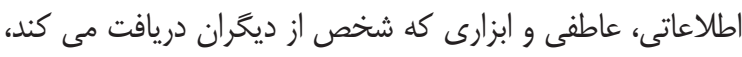

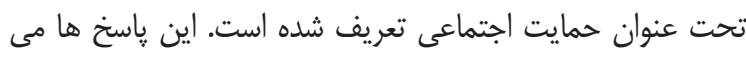

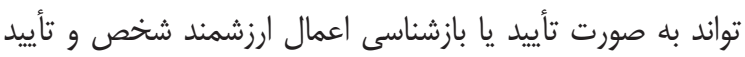

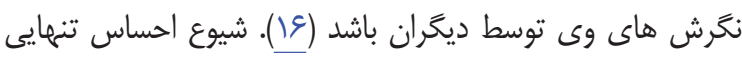

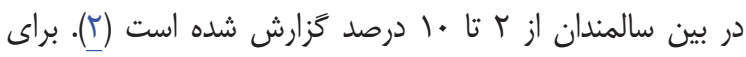

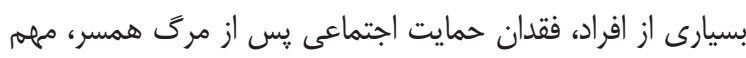

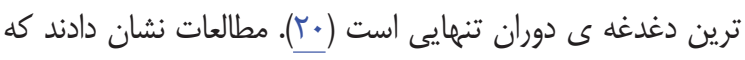
حمايت اجتماعى با كيفيت زندگى سالمندان رابطه معنى دارى دارد

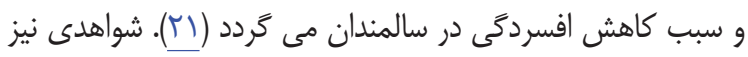

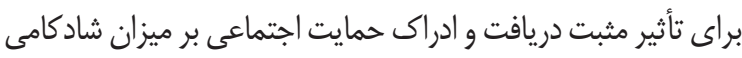

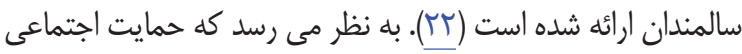

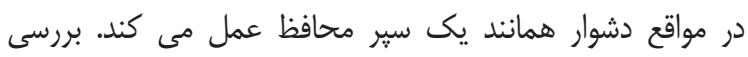
اثرات حمايت اجتماعى و دين دارى به عنوان شيوه هاى انطباق

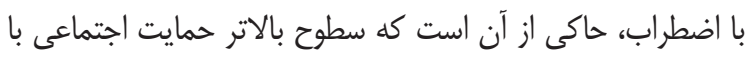

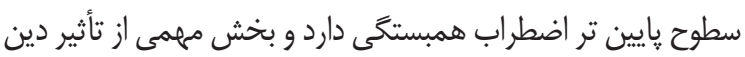
دارى در كاهش اضطراب، از طريق حمايت اجتماعى صورت كرفته

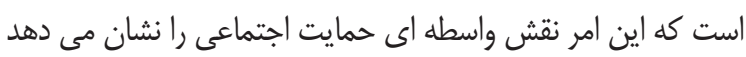

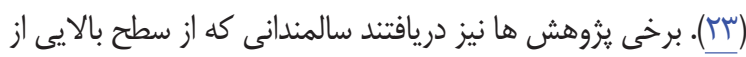
عناصر مذهبى-معنوى در زندگى خود برخوردار بودند، سطح بالاترى درى از حمايت اجتماعى ادراك شده و بهزيستى را در زندكى روزمرهى

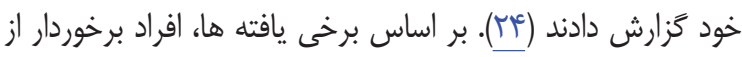

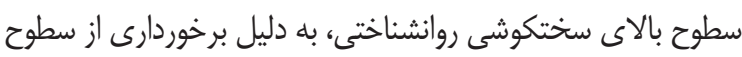

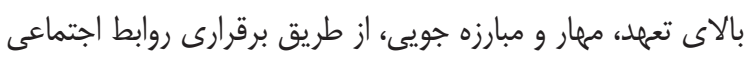

پاسخ به اين سوال نيز مى باشد كه جرا هوش معنوى مى تواند عاملى

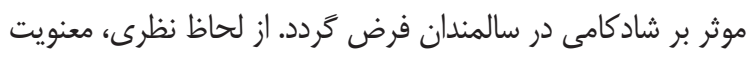

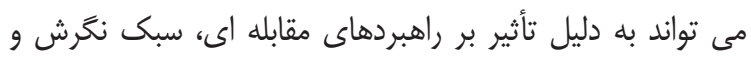

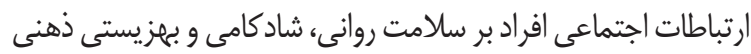
(subjective well-being)

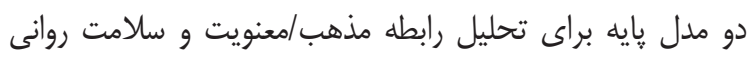
استفاده مى كنند. مدل ضربه كير استرس (stress-buffering (model (1) بر اين فرض مبتنى است كه مذهب/معنويت به افراد كمك مى كند با مشكلات و دشوارى ها در زندَّى شان مقابله كنند.

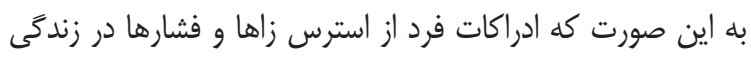

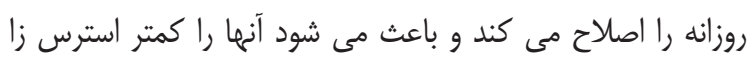

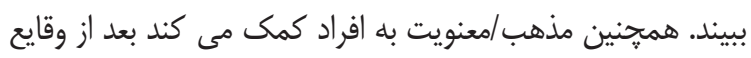
آسيب زا به زندگى ادامه دهند و مفهومى از اميدوارى را براى آنها

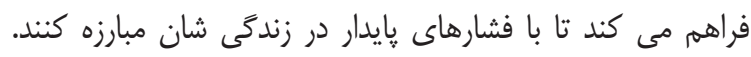

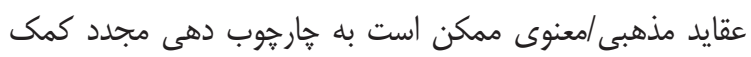

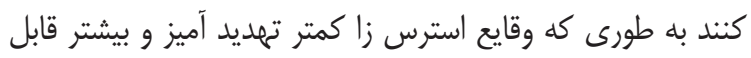
مديريت ديده شوند. از سوى ديخر، مدل اثر اصلى (main affect

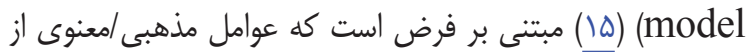
طريق فراهم كردن شبكه هاى اجتماعى يك نقش حمايت اجتماعى

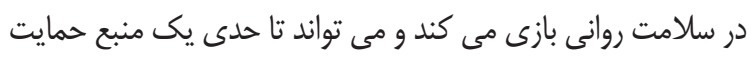

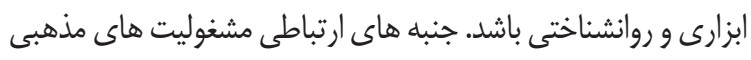

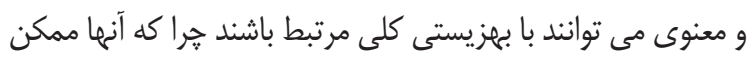

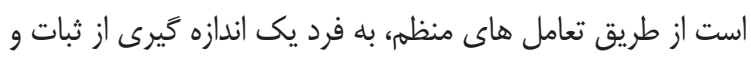
قابليت ييش بينى يذيرى بدهند. از اين رو، به نظر مى رسد در تبيين

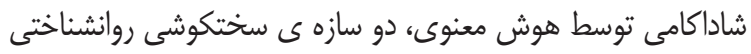
و حمايت اجتماعى قابل توجه باشند.

سختكوشى روانشناختى (psychological hardiness) را يك ويزَى شخصيتى مى دانند كه در هنگام رويارويى با حوادث فشارزاى زندگى، به عنوان يك منبع مقاومت و سير محافظ عمل دئل

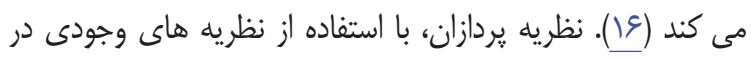

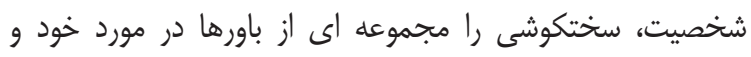
جهان حاضر تعريف مى كنند كه از سه مولفه تعهد، مهار و مبارزه

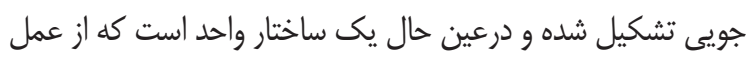
يكيارجه و هماهنگ اين سه مولفه مرتبط با هم منشأ مى گيرد (IV).

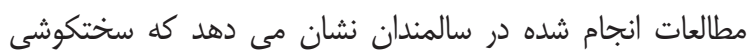

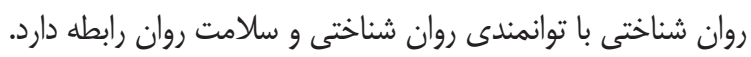
براى نمونه، ززارش شده است كه سلامت روانى سالمندان توسط رون 
با استفاده از تحليل عاملى اكتشافى، ينج عامل رضايت از زندگى،

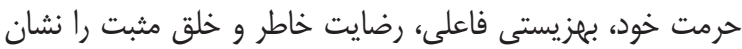
داد و ضريب همسانى كل سياهه (9/. به دست آمد (ه). در اين يزوهش ساختار عاملى OHI-R از طريق تحليل عاملى اكتشافى و تأييدى مورد بررسى قرار كرفت و ضمن انجار عام تغييراتى در تعداد

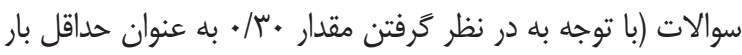

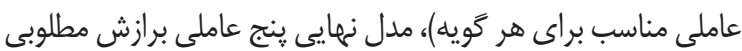
با داده ها داشت (Nه . $(\mathrm{RMSEA}=\cdot 1.99 \mathrm{C} \mathrm{CFI}=\cdot / \wedge \Delta, \mathrm{GFI}=\cdot / \wedge \uparrow ، \mathrm{df} / \chi r=$ همسانى درونى كل مقياس و خرده مقياس هاى رضايت از زندگىى، حرمت خود، بهزيستى فاعلى، رضايت خاطر و خلق مثبت از طريق

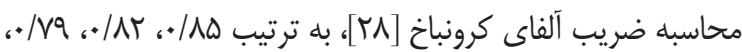
AV سياهه خود-كزارشى هوش معنوى (SISRI): سياهل خود-كزارشى هوش معنوى (The Spiritual Intelligence (Self-Report Inventory طيف ليكرت ينج گزينه اى از به هيج وجه در مورد من صدق نمى كند تا كاملاً در مورد من صدق مى كند) مى بـ باشد كه مولفه هاى هجاركانه اى از هوش معنوى شامل تفكر انتقادى وجودى

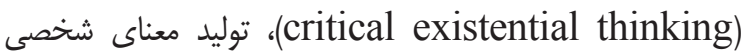
(personal meaning production) و و بسط حالت هشيارى (transcendental awareness) را ا اندازه كيرى مى كند. (conscious state expansion)

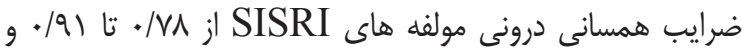

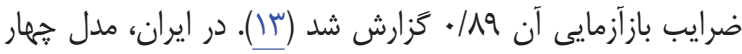

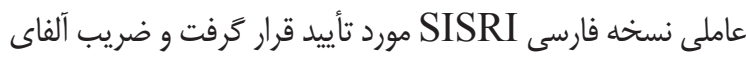
كرونباخ براى نمره كل سياهل، AV/ يزوهش ساختار عاملى SISRI از طريق تحليل عاملى اكتشافى نيل و تأييدى مورد بررسى قرار كرفت و ضمن انجام تغييراتى در تعداد سوالات با توجه به در نظر گرفتن مقدار • •َ/• به عنوان حداقل بار عاملى مناسب براى هر كويه، مدل نهايى جهار عاملى برازش مطلوبى

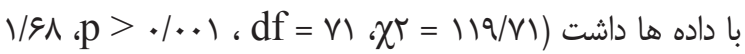
( $(\mathrm{RMSEA}=\cdot / \cdot 9, \mathrm{CFI}=\cdot / 9 \cdot \mathrm{cGFI}=\cdot / 9) ، \mathrm{df} / \chi \mathrm{\chi} r=$ همسانى درونى كل سياهه و خرده مقياس هاى شامل تفكر انتقادى وجودى، توليد معناى شخصى، آكاهى ماورايى و بسط حالت هشيارى درى

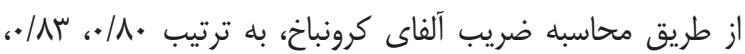
1/NA
با ساير افراد داراى سطح بالاى سختكوشى روانشناختى، حمايت اجتماعى بيشترى را تجربه مى كنند (9). همجنين، تحقيقات ديكر، احساس ييوستخى شامل احساسات يوياى اعتماد به محيط را ييامد سختكوشى روانشناختى دانسته اند و كزارش كردند كه بر همين اساس، سختكوشى روانشناختى باعث مى شود كه شخص به منابع

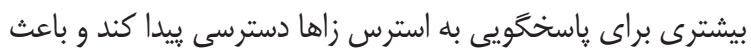

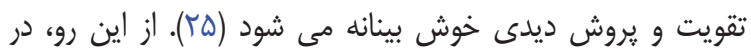
يُوهش حاضر هنين فرض شد كه هوش معنوى از طريق ايجاد

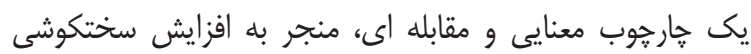

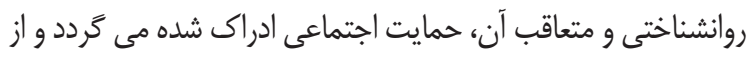

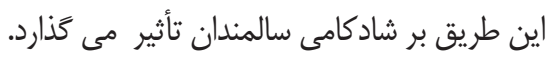

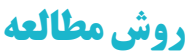

يزوهش حاضر در :اريوب يك طرح همبستىى از نوع

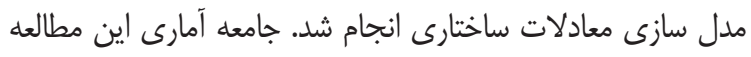

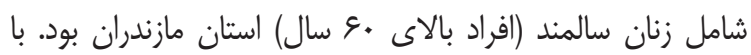
توجه به برخى ييشنهادهاى روش شناختى در مدل سازى معدلات

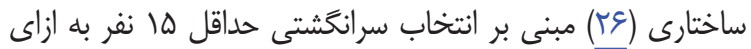

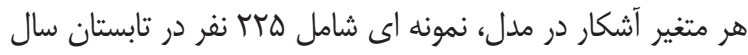

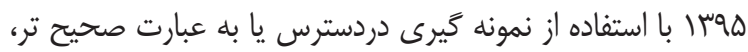

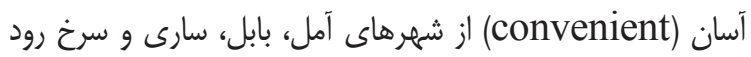

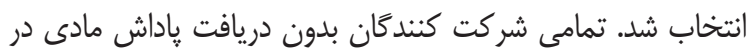
يثروهش شركت كردند. يֶ از حذف مقادير دورافتاده و نيز يرسشنامه

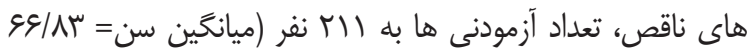

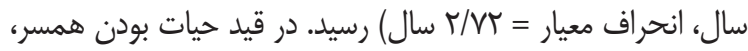

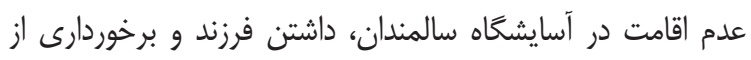
حداقل هشت كلاس سواد به عنوان ملاك ورود در نظر كرفته شد.

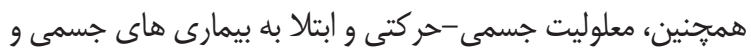
روانى مرتبط با هشيارى، به عنوان ملاك خروج در نظر كرفته شدند. سياهه تجديدنظر شده شادكامى آكسفورد (OHI-R): The Oxford) سياهه تجديدنظر شده شادكامى آكسفورد (Happiness Inventory اى است كه باسخ هاى آن به ترتيب از • تا ب نمره كذارى مى شود

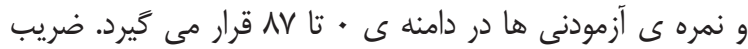

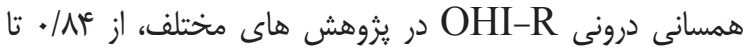

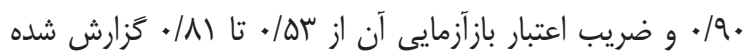

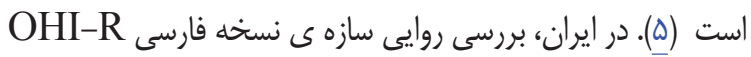


bootstrap) و فرايند خودمردان سازى (estimation

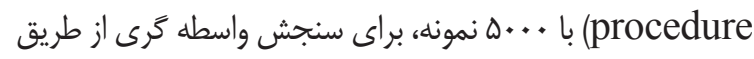

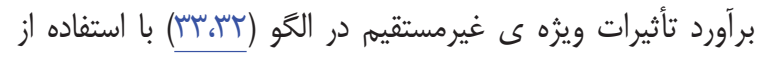

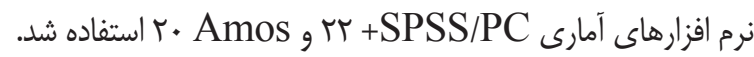

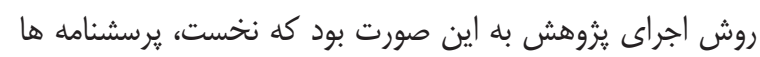

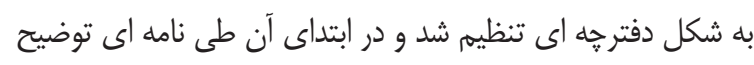
مختصرى در مورد ماهيت روانشناختى يزوهش، محرمانه ماندن

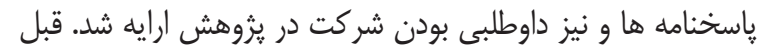

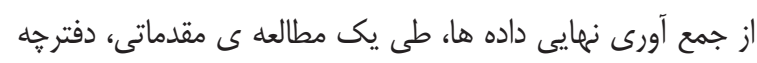

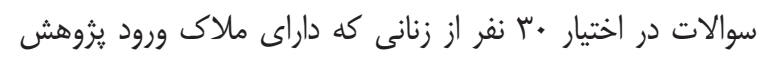

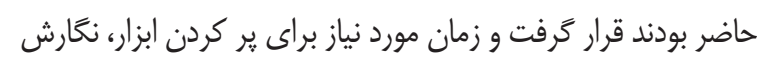

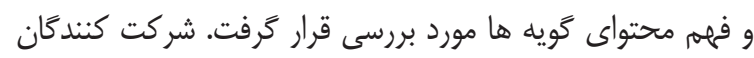

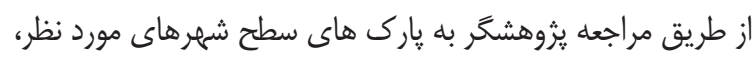
در خار خوب ملاكى هاى ورود و خروج، شناسايى و انتخاب كَرديدند. يبشنهاد اجراى يزوهش در كميته عى علمى گروه روانشناسى دانشخاه

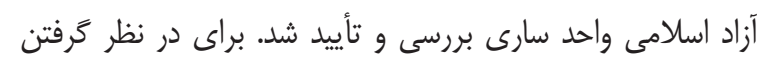

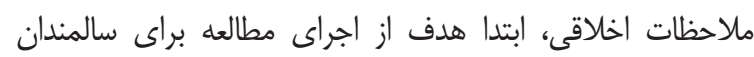

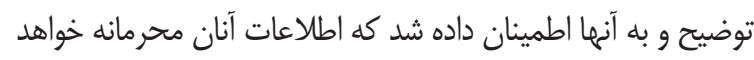
بود و اعلام كرديد كه شركت در مطالعه اختيارى است.

\section{يافْته ها}

ميانخين سن شركت كنندكان در اين يزوهش سمراعو سال

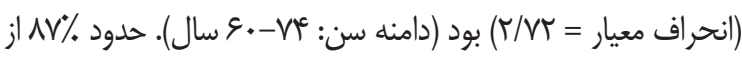

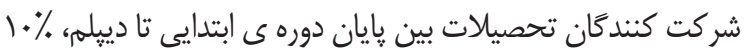

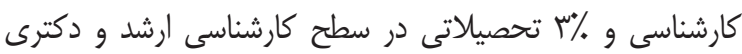

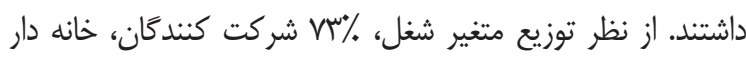

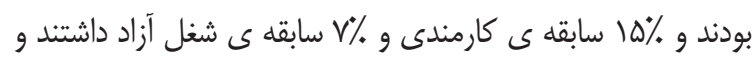

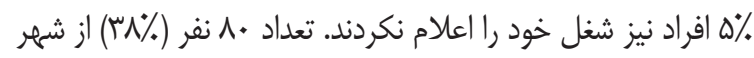

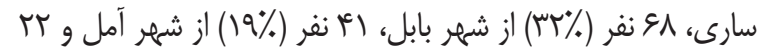
نفر (11\%) نيز از شهر سرخ رود انتخاب شدند. (جدول () ميانخين و انحراف معيار هوش معنوى، سختكوشى روانشناختى، حمايت

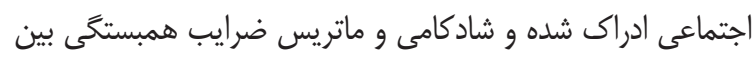

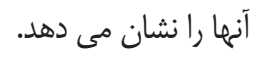

مقياس سرسختى اهواز (AHI): مقياس سرسختى اهواز (Ahvaz Hardiness Inventory) باشد. هر ماده داراى جهار زَينه ياسخ است كه شامل هركز، به ندرت، كاهى اوقات و اغلب اوقات مى باشد و به ترتيب نمره هاى

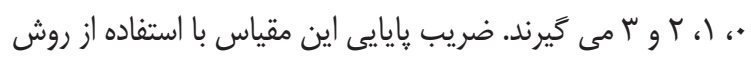

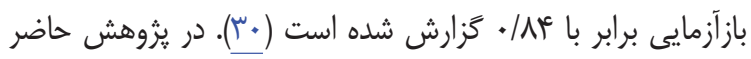

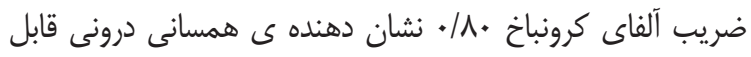
قبول اين مقياس بود.

مقياس קند بعدى حمايت اجتماعى ادراك شده (MSPSS) Multidimensional Scale of Perceived Social) Support (اسّ)، مركب از rا گويه است كه سه مولفه حمايت

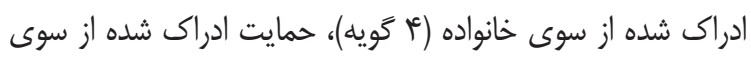

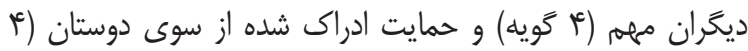
كويه) را سنجش مى كند. همه كَيه هاى اين مقياس، بر اساس يكى طيف ه درجه اى (بسيار موافق، موافق، نه موافق و نه مخالف،

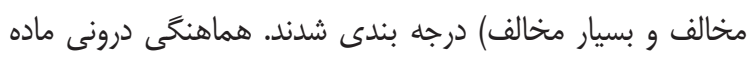
هاى مقياس حمايت اجتماعى با استفاده از روش آلفاى كرونباخ، به

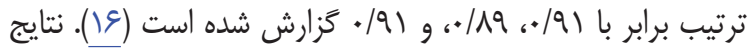

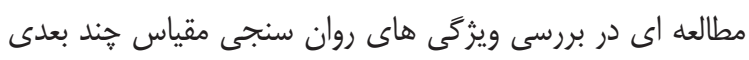
حمايت اجتماعى ادراك شده با استفاده از تحليل عاملى تاييدى نشان مان

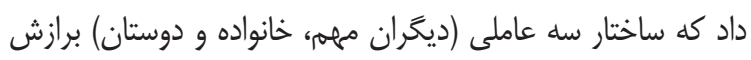
قابل قبولى با داده ها دارد (1). ضرايب آلفاى كرونباخ عامل كلى إنى حمايت اجتماعى ادراك شده و مولفه هاى (ديخران مهم، خانواده

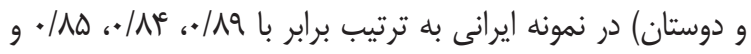

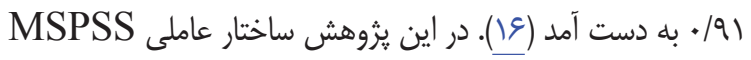

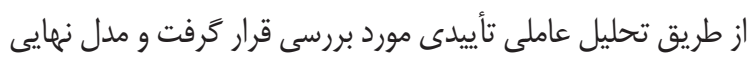

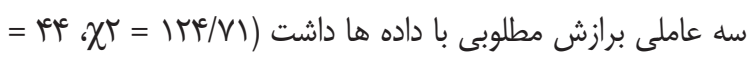

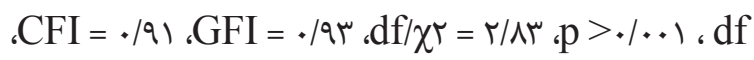
RMSEA = •/•WV براى كل مقياس و زيرمقياس هاى حمايت ادراك شده از سوى دي خانواده، حمايت ادراك شده از سوى ديگران مهم و حمايت ادراك هاي

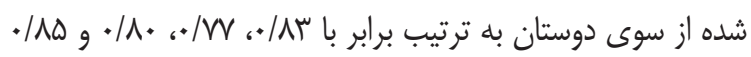
محاسبه شد.

جهت تحليل داده ها، علاوه بر شاخص هاى آمار توصيفى،

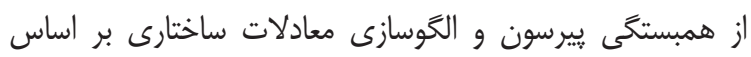
برآورد حداكثر درست نمايى Maximum Likelihood) 


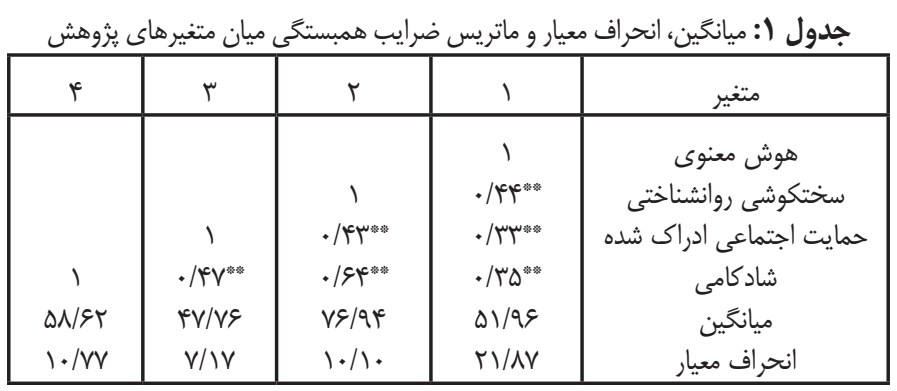

$\mathrm{p}<. \cdot 1, * \mathrm{p}<. . \Delta * *$

شاخص تعديل شده نيكويى برازش (AGFI)، مطلوب كزارش شده

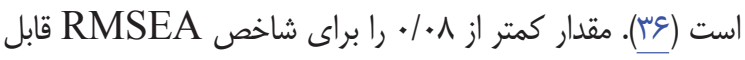

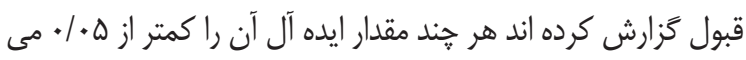

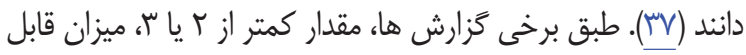

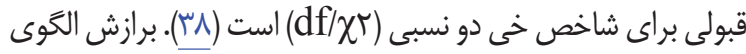
مفروض ثروهش حاضر، با استفاده از برآورد حداكثر درست نمايى برايى

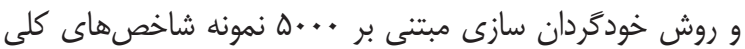

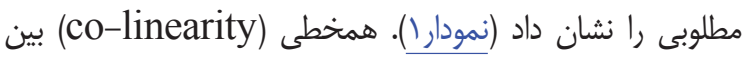
متغيرها از طريق شاخص هاى تورم واريانس (VIF) Variance Inflation Index

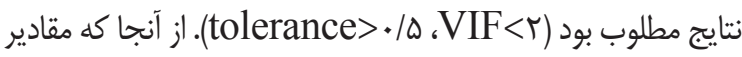
dr به طور قابل تمايزى مجزا نبودند (عب)، از لحاظ دورافتادكى جندمتغيرى (multivariate outliers) نيز مشكلى وجود نداشت. نتايج مربوط به شاخص هاى برازش و ضرايب استاندارد مستقيم در (نمودار ا ) ارائه شده است.
از آزمون خى دو (Yَ) كه ميزان تفاوت ماتريس هاى

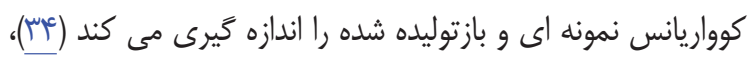

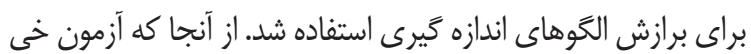
دو به نمونه هاى با حجم بزرى حساس است (هَّ)، شاخص هاى ديخرى از جمله شاخص هاى مطلق (absolute fit indices)

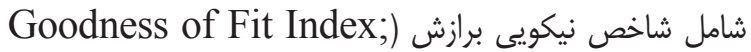
Adjusted و شاخص تعديل شده نيكويى برازش (GFI Goodness-of-Fit Index; AGFI واريانس ها و كوواريانس هاى مشاهده شده از يك طرف و واريانس ها و كواريانس هاى ييش بينى شده بر مبناى بارامترهاى الكَوى

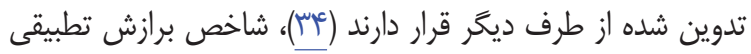
(Comparative Fit Index; CFI)

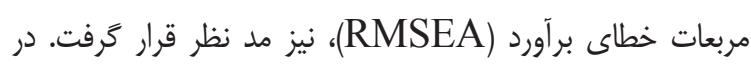

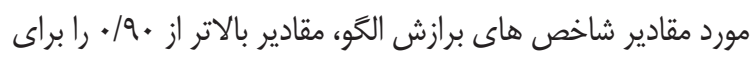
شاخص برازش تطبيقى (CFI)، شاخص نيكويى برازش (GFI) و

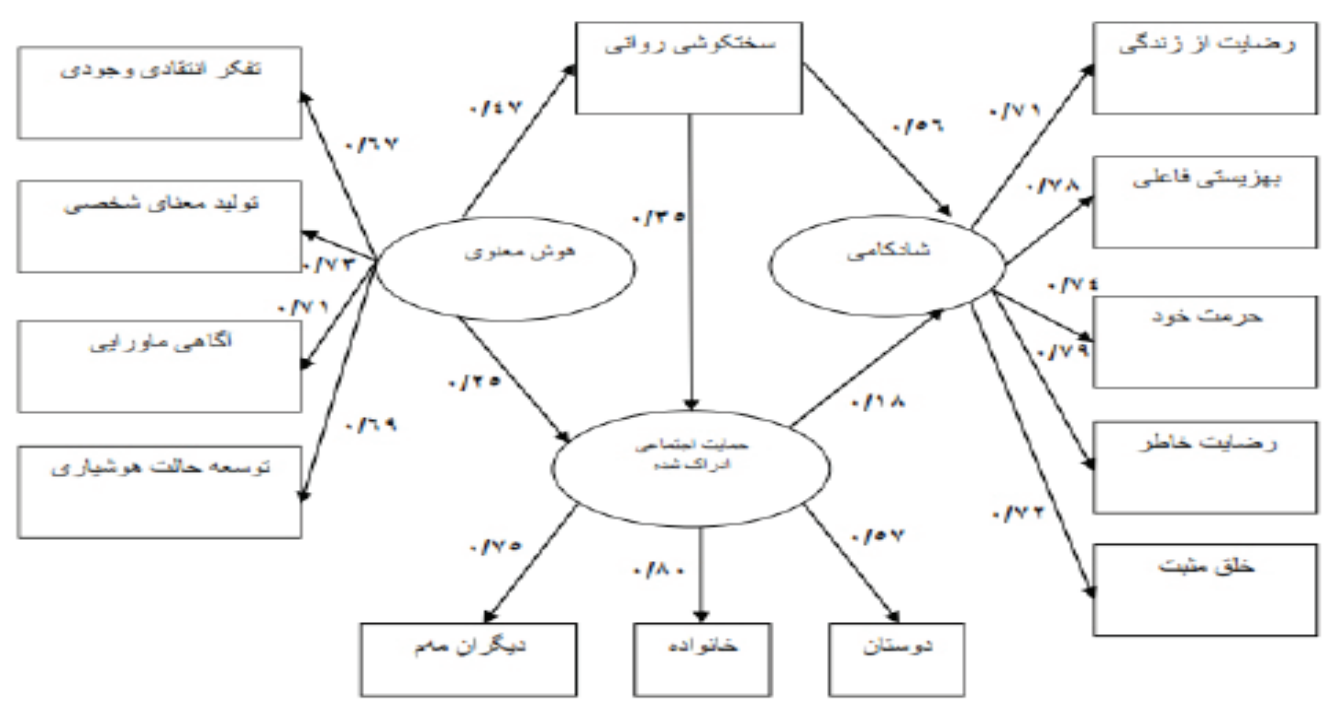

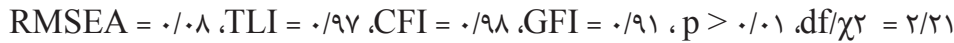

شكل (: ضرايب استاندارد مستقيم الكوى مفهومى روابط ميان هوش معنوى، سختكوشى روانشناختى، حمايت اجتماعى ادراك شده و شادكامى در سالمندان 
ادراك شده بر شادكامى (1/ / +، ه + | > > p نيز مطابق انتظار، مثبت

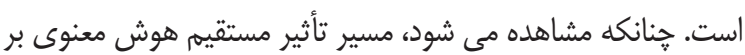
شادكامى در برازش الخوى مفهومى يثوهش حاضر، معنى دار نشد و از الخو حذف گرديد. در (جدول r) بر آورد ضرايب تأثير غيرمستقيم و ضرايب تأثير كل مربوط به آنها كزارش شده است. برأ

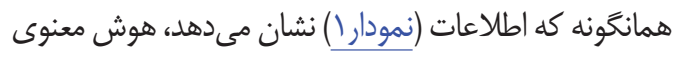

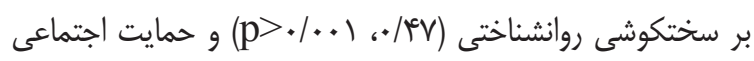

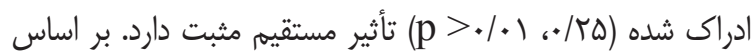
يافته هاى مندرج در (نمودار ()، سختكوشى روانشناختى بر حمايت

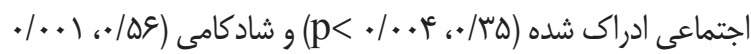
تأثير مستقيم مثبت دارد و تأثير مستقيم حمايت اجتماعى (p< جدول ك: بر آورد ضرايب تأثير غير مستقيم و كل الحوى واسطه ایى روابط بين هوش معنوى، سختكوشى روانشناختى، حمايت اجتماعى ادراك شده و شادكامى در سالمندان

\begin{tabular}{|c|c|c|c|}
\hline \multicolumn{2}{|c|}{ اثر } & \multicolumn{2}{|c|}{ متغير } \\
\hline كل & غيرمستقيم & ملاكى & ييش بين \\
\hline.$/ 41$ &.$/ 19$ & حمايت اجتماعى & هوش معنوى \\
\hline سז/. & سז/. & شادكامى & هوش معنوى \\
\hline .194 & .1 .9 & شادكامى & سختكوشى \\
\hline
\end{tabular}

معنوى، توانايى سازگارى فرد با محيط معرفى شده است. به عبارتى

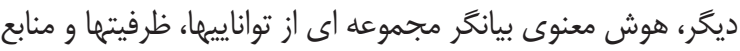

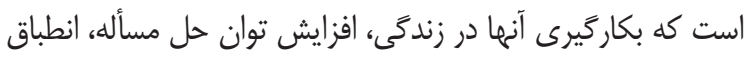
يذيرى و بهزيستى روانشناختى را در يیى خواهد داشت. از آنجا كه آنه

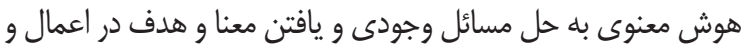
رويدادهاى زندگى روزمره كمك ميكند، اين امكان را براى فرد فر فراهم مى نمايد كه بر اساس نظام شناختى مبتنى بر معنا و تفسير موقعيت روني

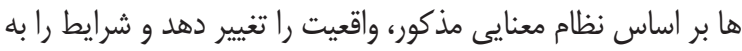

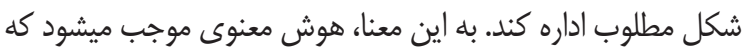

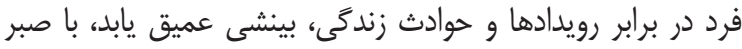

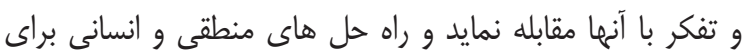

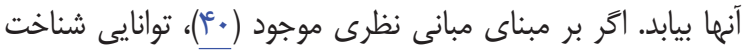

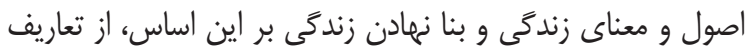

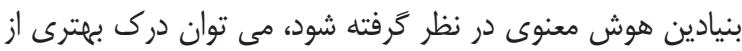

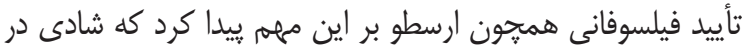

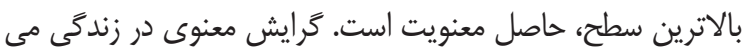

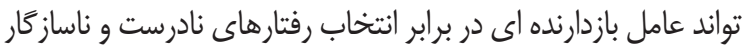
باشد و در نهايت منجر به سطح بالايى از بهزيستى روانشناختى و

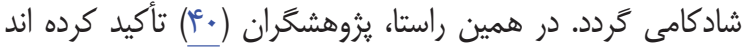
فردى كه از هوش معنوى استفاده مى كند مى تواند براى تجربيات

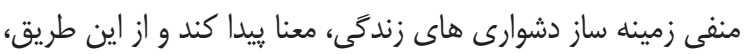

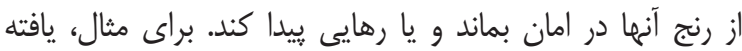

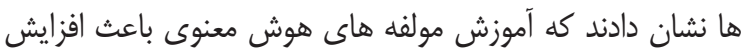

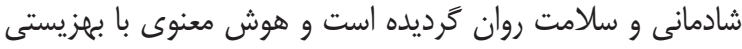

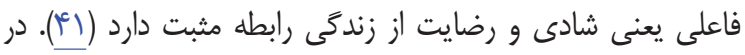
تأييد تبيين هاى فوق، هوش معنوى از سوى يزوهشگًران، سازه

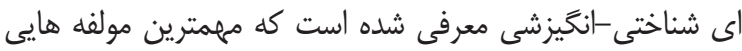

يافته هاى حاصل از روش خودگردان سازى نشان داد كه

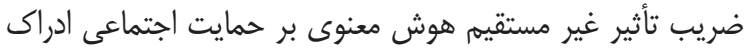

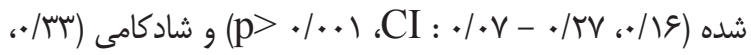

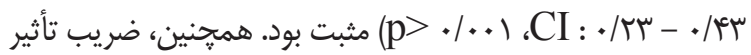
غير مستقيه سختكوشى روانشناختى بر شادكامى (و+|+، IV/.

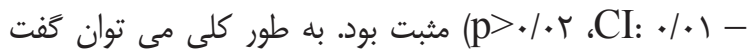
تمامى فرضيه هاى يزوهش به غير از تأثير مستقيم هوش معنوى بر

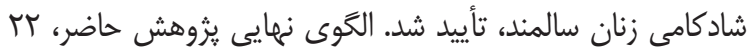

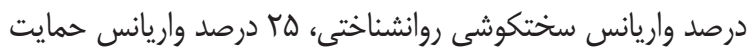
اجتماعى ادراك شده و عأ درصد واريانس شادكامى را تبيين نمود.

هدف از مطالعه ى حاضر، آزمون يك الخَى مفهومى

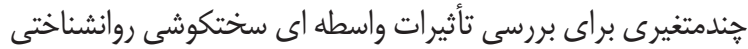

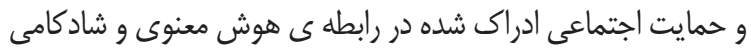

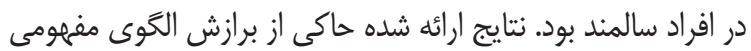

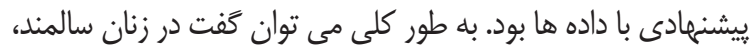

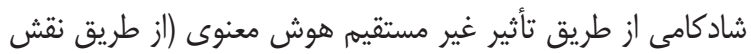
واسطه اى سختكوشى روانشناختى و حمايت اجتماعى ادراك شده)،

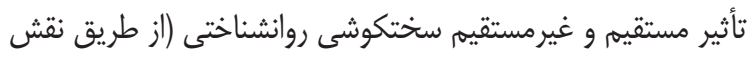
واسطه اى حمايت اجتماعى ادراك شده) و تأثير مستقيم حمايت

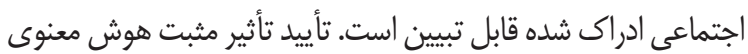

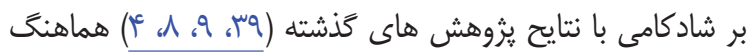
است. به طور كلى در تبيين يافته هاى يزوهش حاضر مى توان كفت بال

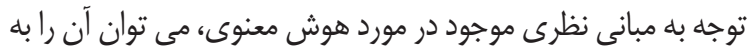

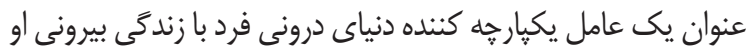

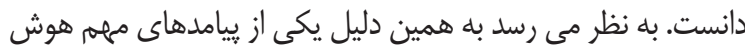


اساس، مى توان كفت حمايت اجتماعى ادراك شده مى تواند واسطه

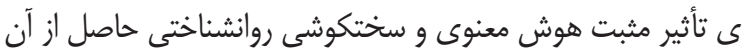

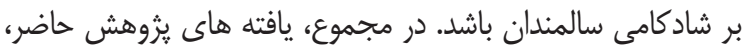

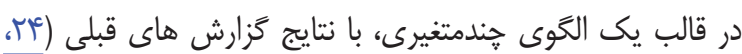

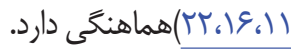
در تعميم يافته هاى يزوهش حاضر، توجه به محدوديت

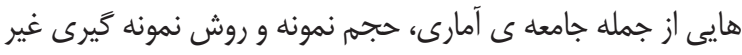

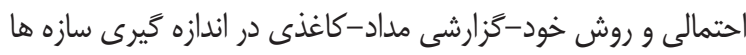

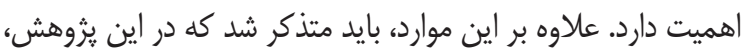
دادهها در يك مقطع زمانى خاص به دست آمد.

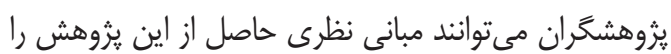
ملاك قرار بدهند و بر اساس آن فرضيههاى متعددى را مطرح و و ترني

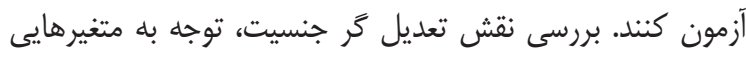

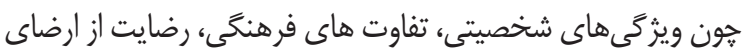
نيازهاى بنيادين روانشناختى، وضعيت اقتصادى-اجتماعى و از اين

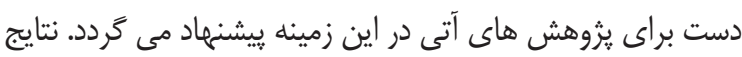

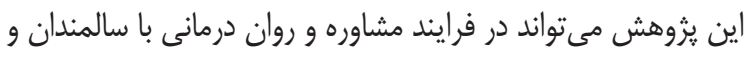

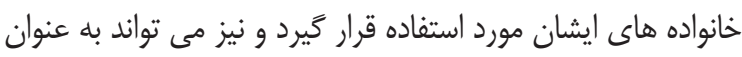

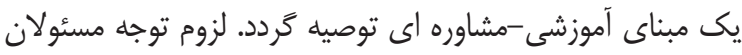

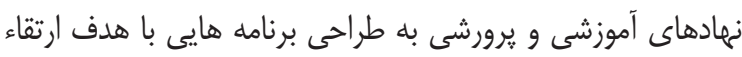

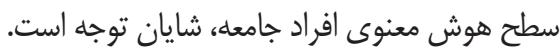

\section{تُتيجه تَيرى نُهايى}

بر اساس يافته هاى يُووهش حاضر مى توان خُنين نتيجه كرفت كه سطوح بالاتر هوش معنوى مى تواند شادكامى بالاترى ران ران در سالمندان بيش بينى كند. در اين ميان، سختكوشى روانشناختى

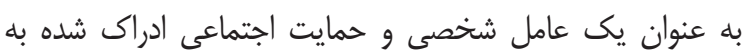

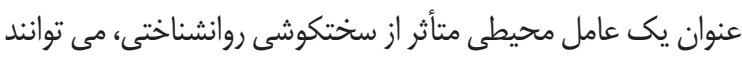

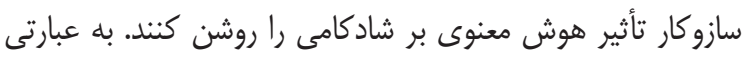
ديخر، هوش معنوى از طريق افزايش سختكوشى روانشناختى و باريه تبع آن افزايش حمايت اجتماعى ادراك شده، بر شادكامى سالمندان تأثير مثبت دارد.

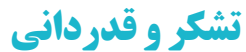

موضوع يزوهش حاضر ارتباطى با منافع نويسندكان ندارد و

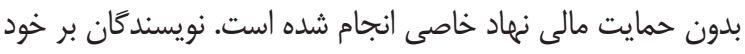

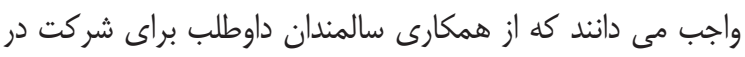
يزوهش قدردانى نمايند.
كه نشان دهنده هوش معنوى رشديافته هستند عبارتند از صراحت،

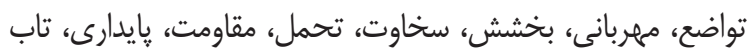

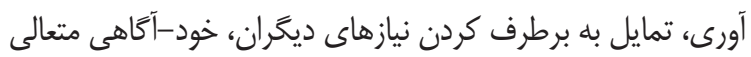

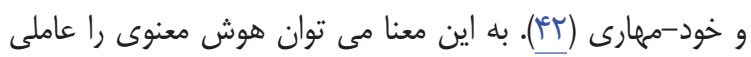

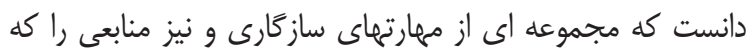
حل مسئله و دستيابى به هدف را تسهيل مى كنتند، معرفى مى نمائ نمايد

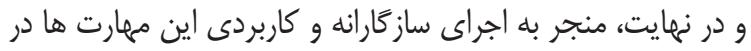

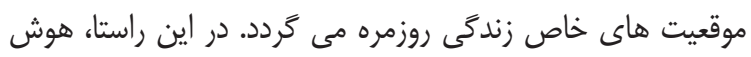

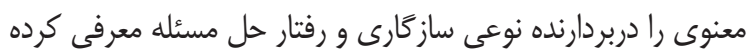
اند كه بالاترين سطح رشد رادر حيطه هاى مختلف شناختى، اخلاقى،

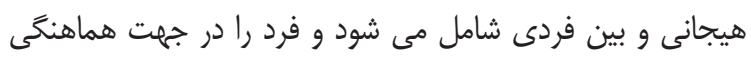

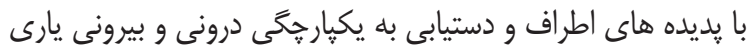

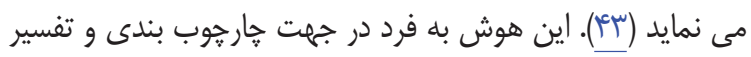
مجدد تجارب خود كمك شايان توجهى خواهد كرد كه مى توان

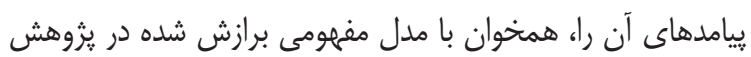

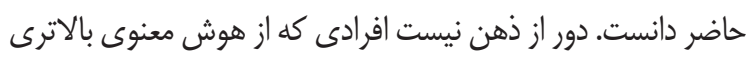

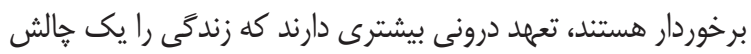

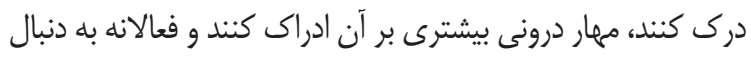

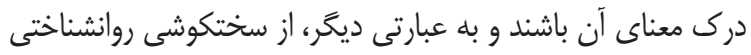

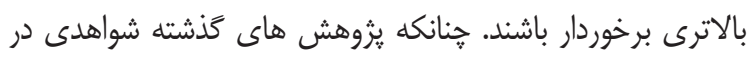

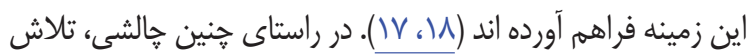
براى ايجاد شبكه هاى اجتماعى و روابط داراى بار افزاينده ى مع معنا

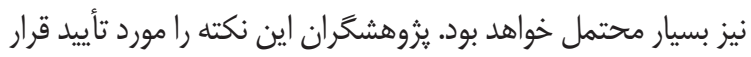

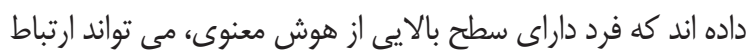

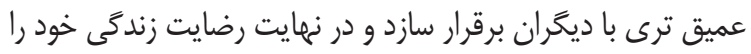

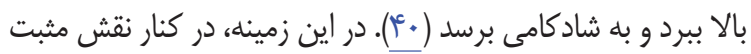

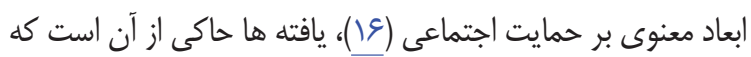

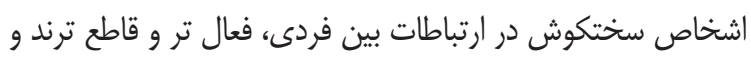
به نزديكى با اشخاصى كه از سختكوشى بالايى برخوردارند، تمايل

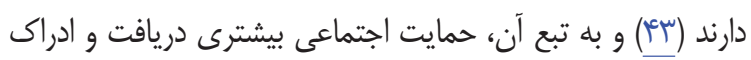

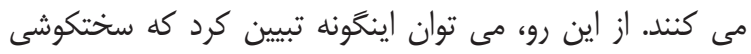

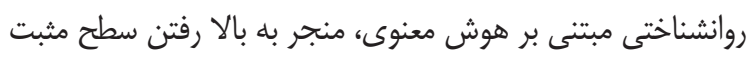

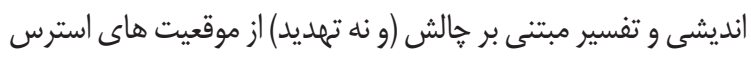

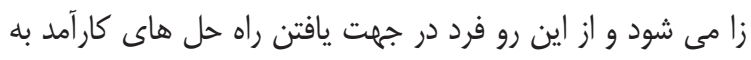

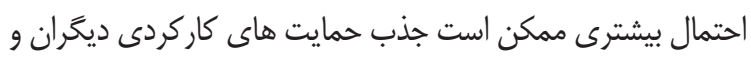
به ويثة افراد برخوردار از سطح بالاى سختكوشى روانشناختى كرد درد.

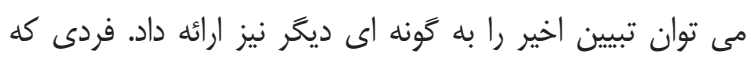
به خاطر سطح بالاى هوش معنوى، سختكوشى روانشناختى بالايى إنى دارد، مى تواند براى ساير افراد جذابيت داشته باشد. از اين رو، تمايل

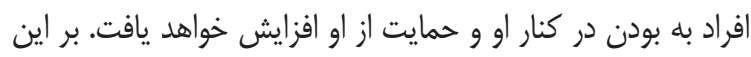




\section{References}

1. Siedlecki KL, Salthouse TA, Oishi S, Jeswani S. The relationship between social support and subjective well-being across age. Social Indicators Research. 2014; 117 (2): 561-576.

2. Zanjiran S, Keyani L, Zare M, Shayeghian Z. The effectiveness of group logotherapy on the sense of loneliness of eldery women resident in nursing home. Knowledge \& Research in Applied Psychology. 2015; 16(3): 60-67. [Persian].

3. Ford TE, Lappi SK, Holden CJ. Personality, Humor Styles and Happiness: Happy People Have Positive Humor Styles. Europe's Journal of Psychology. 2016; 12 (3): 320-337. doi:10.5964/ ejop.v12i3.1160.

4. Shukla P, Kiran UV. Subjective Happiness among the Elderly across Various Groups. Journal of Humanities and Social Science (IOSR-JHSS). 2013; 13(6): 46-49.

5. Alipour A, Agah Heris M. Reliability and validity of the Oxford Happiness Inventory among Iranians. Journal of Iranian Psychologists. 2007; 3 (12): 288-289. [Persian].

6. Alavi S, Zar AS, Salimi Avansar M, Ahmadi F. Evaluate the effectiveness of physical activity on general health, happiness and life expectancy in postmenopausal and older women. Journal of Gerontology. 2017; 2 (1): 11-19. [Persian].

7. Lawrence EM, Rogers RG, Wadsworth $\mathrm{T}$. Happiness and Longevity in the United States. Social Science and Medicine. 2015; 145: 115119.

8. Fisher J. You can't beat relating with God for spiritual well-being: Comparing a generic version with the original spiritual well-being questionnaire called SHALOM. Religions. 2013; 4 (3): 325-335.

9. Rebecca P, Jiaqing O. Association between caregiving in life, life satisfaction and quality of life, beyond 50 in an Asian sample: Age as a moderator. Social Indicators Research. 2011; 108 (3): 525-534.

10. Jafari A, Hesampour F. Predicting Life Satisfaction Based On Spiritual Intelligence and Psychological Capital in Older People. Iranian Journal of Aging. 2017; 12(1): In press. [Persian].
11. Jafari E, Hajloo N, Faghani R, Khazan K. The relationship between spiritual well-being, hardiness, and mental health in the elderly. Journal of Research in Behavioural Sciences. 2012; 6(10): 431-440. [Persian].

12. Adler MG, Fagley NS. Appreciation: individual difference in finding value and meaning as a unique predictor of subjective well-being. Journal of personality. 2005; 73(1): 79-114.

13. King DB. Rethinking claims of spiritual intelligence: A definition, model, and measure. [Unpublished Master's Thesis]. Trent University, Peterborough, Ontario; 2008.

14. Babanazari L, Askari P, Mehrabizadeh Honarmand M. Spiritual intelligence and happiness for adolescents in high school. Life Science Journal. 2012; 9(3); 2296-2299.

15. Mirola, WA. A refuge for some: Gender differences in the relationship between religious involvement and depression. Sociology of Religion. 1999; 60 (4): 419-437.

16. Mahdian Z, Ghaffari M. The mediating role of psychological resilience, and social support on the relationship between spiritual well-being and hope in cancer patients. Journal of Fundamentals of Mental Health. 2016 May-Jun; 18 (3): 130138.

17. Sharifi K, Oreyzi H, Namdari K. A study of the relationship between family functioning and psychological hardiness of high school students in Isfahan. CPAP 2005; 1(10): 85-94. [Persian].

18. Ya'qubi A, Mohagheghi H, Monazami Tabar F. The Relationship of Spiritual Well-being and Hope with Life Satisfaction among the Aged. Psychology and Religion. 2014; 27: 109-121. [Persian].

19. Salmabadi M, Khamesan A, Usefynezhad A, Sheikhipoor M. The mediating role of spiritual intelligence in relationship of mindfulness and resilience. Health, Spirituality and Medical Ethics. 2016; 3 (3): 18-24.

20. Khodabakhsi-Koolaee A, Mirafzal NS. Relationship between humor and social support with sex satisfaction in elderly married women. Journal of Gerontology. 2017; 2 (1): 1-10. [Persian]. 
21. Hekmatipour N, Taheri N, Hojjati H, Rabiee S. Evaluation of the Relationship between Social Support and Quality of Life in Elderly Patients with Diabetes. J Diabetes Nurs. 2015; 3 (1): 42 50.

22. Jeon SW, Han C, Lee J, Lim J, Jeong HG, Park MH, Ko YH, Pae CU, Kim SH, Joe SH, Steffens DC. Perspectives on the happiness of communitydwelling elderly in Korea. Psychiatry Investig. 2016; 13 (1): 50-57.

23. Hughes JW, Tomlinson A, Blumenthal JA, Davidson J, Sketch MH, Watkins LL. Social support and religiosity as coping strategies for anxiety in hospitalized cardiac patients. Ann Behav Med. 2004; 28 (3):179-185. DOI: 10.1207/s15324796abm28036.

24. Al-Kandari Y. Religiosity, social support, and health among the elderly in Kuwait. Journal of Muslim Mental Health. 2011; 6 (1): 81-98.

25. Hasanneghad N, Hadavandkhani F, Ahmadi P, Khanjani Z. Relationship between Psychological Hardiness and Social Support with Adaptation: A Study on Individuals with Multiple Sclerosis. J Shahid Sadoughi Univ Med Sci 2013; 21 (4): 465-74. [Persian].

26. Hooman HA. Structural Equation Modeling with Lisrel application. Tehran: Samt; 2005. [Persian].

27. Car A. Positive psychology: The science of happiness and human strengths. New York: Brunner-Routledge Ltd; 2004.

28. Cronbach LJ. Essentials of psychological testing. New York: Harper and Raw International; 1970.

29. Hamidi F, Sedaghat H. Comparison of spiritual intelligence between high school students according to their genders and grades. Woman in Culture and Art (Women's Research). 2012; 4 (4): 75-88. [Persian].

30. Kiyamersi A, Najariyan B, Mehrabi zade H. Construction and Validation of a measure of psychological hardiness. Journal of Psychology 1998; 7 (2): 271-284. [Persian].

31. Zimet GD, Dahlem NW, Zimet SG, Farley GK. The multidimensional scale of perceived social support. Journal of Personality Assessment 1988; 52: 30-41.

32. Preacher KJ, Hayes AF. Asymptotic and resampling strategies for assessing and comparing indirect effects in multiple mediator models. Behavior Research Methods. 2008; 40 : 879-891.

33. Hayes AF. Beyond Barron and Kenny: Statistical mediation analysis in the new millennium. Communication Monographs. 2009; 76: 408-20.

34. Ghasemi V. Structural equation modeling in social researches using Amos Graphics. Tehran: Jameeshenasan; 2010. [Persian].

35. Stevens J. Applied multivariate statistics for the social sciences (3rd ed.). Mahwah, NJ: Lawrence Erlbaum Associates; 1996.

36. Byrne BM. Structural equation modeling with AMOS (2nd ed.). New York: Routledge; 2010.

37. Browne MW, Cudeck R. Alternative ways of assessing model fit. In K. A. Bollen \& J. S. Long (Eds.), Testing structural equation models. Newsbury Park, CA: Sage; 1993: 136-162.

38. Ullman JB. Structural equation modeling. In B. G. Tabachnick \& L. S. Fidell (2001). Using Multivariate Statistics (4th ed). Needham Heights, MA: Allyn \& Bacon; 2001: 653-771.

39. Zamirinejad S, Piltan M, Haghshenas M, Tabaraie Y, Akabery A. Prediction of students' happiness, based on spiritual intelligence. Journal of Sabzevar University of Medical Sciences. 2014; 20 (5): 781-773. [Persian].

40. Heydari A, Koroshnia M, Hosseini SM. The mediating role of psychological well-being in the relationship between Spiritual intelligence and happiness. Journal of Psychological Methods and Models. 2015; 6 (21): 73-86. [Persian].

41. Amini Javid L, Zandi Pour T, Karami J. The effectiveness of spiritual intelligence training on female students' depression and happiness. Quarterly Journal of Woman and Society. 2015; 6 (22): 141-168. [Persian].

42. Keshavarzi S, Yousefi F. The relationship between emotional intelligence, spiritual intelligence and resilience. 2012; 16 (3): 299-318. [Persian].

43. Maddi SR. Issues and intervention in stress mastery. In (ED). Personality and disease. Friend man, S. H (ED). Personality and Disease. New York: Mc Graw. 